\section{Just Around Home}

Kenneth Knox, Clair

$\mathbf{M}^{\mathrm{A}}$ ANY birds made their homes right arcund us this past summer. In an area of not more than three acres, nests were built and the following families were raised to maturity. Wrens 4, Robins 2, Mountain Blliebirds 3, Barn Swallows 2 and Yellow Warblers 1.

These nests were all located near my home, the most of them nested in the area around the house, the rest in the barnyard. I could not help but have a pair of Catbirds destroyed this year, and I had good reason for doing so. I located their nest early and left it alone in the hope that they would stay on their side of the fence, so to speak. Actually their nest also was in the house yard. However, I soon noticed that ther were around some of the other birds' nesting places more than their own, and remembering what they did last year to a Bluebird's nest, I decided that I couldn't stay around and protect all the other birds' nests from this destroyer.

By having the pair destroyed all the rest of the birds had no trouble in raising their families. I surelv prefer having the birds mentioned above than a pair of Catbirds.

As far as plumage is concerned, the Bluebirds, Warblers, etc. are far more colourful, and I believe that their songs are much more pleasant. All that I have heard out of a Catbird is a continual "wa, wa, wa". probably it takes a few years for them to develop musical notes.

I am quite sure that there was another nest of Catbirds across the road. They were not disturbed. They would be as welcome as all other birds if only they could be trusted.

I greatly missed the Baltimore Oriole's visit this year, but hope they will return to us next year. Just a few days ago I happened to look out of a window, and there was none other than the Blue Jay himself. It was the first one that I had seen for about six years.

Talking about the Blue Jay, I think the BLUE JAY magazine is a great publication. Had it not been for $\mathrm{Mr}$. Yerex telling me about it, I would have missed a lot of enjoyment that I have already had through reading the magazine.
Ruffed Grouse Rhumba Fred G. Bard

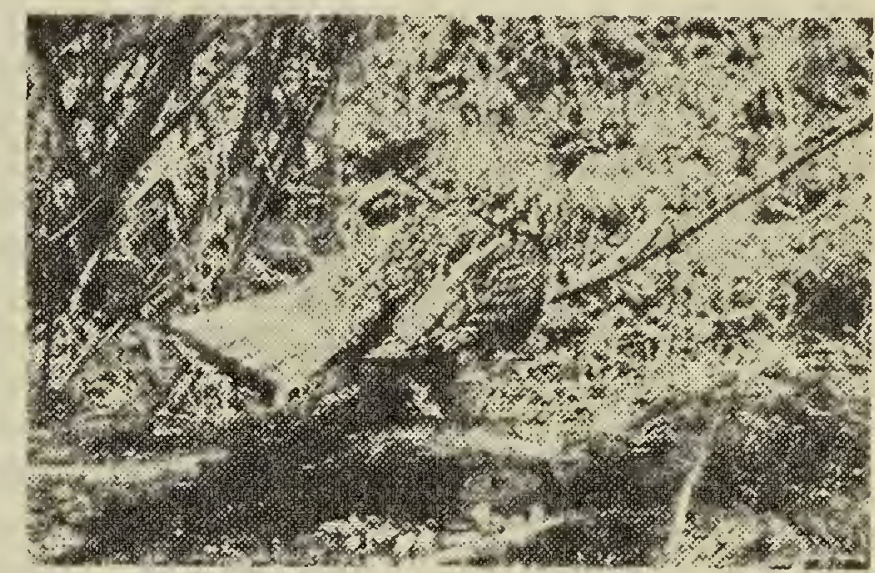

-Photo by Bard.

N November 8th while on field work along the Pipestone, south of Whitewood, I saw a most unusual sight. The moon was already well up and the afternoon drawing to a close. Ernerging from a poplar bluff, I came upon a grassy clearing. In the centre was a Ruffed Grouse shaking its head, its tail fanned out, its ruffs spread and extended forward, framing the head.

Then to my surprise it took three steps, hopped forward and shook its head, then lowering the head it a lmost touched the ground and finished this by resuming again a normal pose. It paused for a few seconds with the tail fanned out, its ruffs extended forward much like a strutting gobbler. The performance was repeated; three steps-a hophead shaking-lowering the head nearly to the ground-resuming normal position. Rehearsing this dance at least twenty times, it crossed the grassy clearing and disappeared into the poplar bluffs on the far side, still dancing the "Ruffed Grouse Rhumba," as only a Ruffed Grouse could.

In this $p e r$ f e ct fall setting I wondered, "Is this", as I have heard, "the season of the crazy moon?" Surely this strange ritual must be sheer exhuberance.
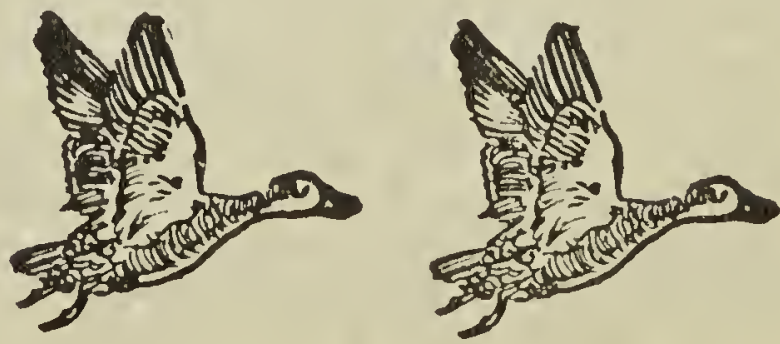